\title{
Studi ruang terbuka hijau dalam kebijakan pengelolaan lingkungan hidup Pemerintah Kota Semarang
}

\section{Supratiwi}

\author{
Universitas Diponegoro, Indonesia
}

\section{KATA KUNCI}

Kebijakan; Pengelolaan Lingkungan Hidup; Ruang Terbuka Hijau

\section{Korespodensi:}

Departemen Politik dan Pemerintahan, Fakultas IImu Sosial dan IImu Politik, Universitas Diponegoro.

Email: tiwik75@gmail.com. 


\section{Pendahuluan}

L ingkungan hidup Indonesia yang dulu dikenal sangat ramah dan hijau kini seakan berubah menjadi ancaman bagi masyarakatnya. Tingkat kerusakan lingkungan di Indonesia sangat besar. Salah satunya bisa dilihat informasi dari Pusat Pengendalian Dampak Lingkungan Kementrian Lingkungan Hidup, bahwa kualitas air sungai di 32 provinsi di Indonesia $82 \%$ tercemar berat, $13 \%$ tercemar sedang, $3 \%$ tercemar ringan, dan hanya $2 \%$ saja yang memenuhi kriteria sungai yang layak. Hal ini tentu saja menjadi perhatian dunia, sebab pencemaran di Indonesia telah melebih ambang batas (Maulana, 2012).

Proses pembangunan yang dilaksanakan di Indonesia selama ini, di samping telah mencapai berbagai kemajuan di segala bidang, ternyata tidak dapat dipungkiri masih menyisakan permasalahan yang justru bersifat kontra-produktif dalam upaya perwujudan ruang kehidupan yang nyaman, produktif, dan berkelanjutan. Berbagai isu strategis bidang lingkungan yang dihadapi bangsa Indonesia saat ini diantaranya, pertama, alih fungsi lahan yang tidak terkendali, baik di kawasan lindung maupun kawasan budidaya yang berdampak pada rusaknya keseimbangan ekosistem dan penurunan produktivitas. Kedua, semakin meningkatnya intensitas dan cakupan bencana alam, terutama banjir dan tanah longsor, yang secara langsung mengancam kehidupan manusia, kegiatan usaha, serta sarana dan prasarana. Ketiga, semakin meningkatnya intensitas kemacetan lalu lintas di kawasan perkotaan, yang berdampak pada inefisiensi koleksi dan distribusi barang dan jasa yang pada gilirannya dapat menurunkan daya saing kawasan dan produk yang dihasilkan. Keempat, semakin menurunnya ruang terbuka hijau, terutama di kawasan perkotaan, yang berakibat pada penurunan kualitas lingkungan. Fakta-fakta di atas menunjukkan bahwa upaya mewujudkan ruang kehidupan yang nyaman, produktif, dan berkelanjutan masih menghadapi tantangan yang berat di masa mendatang.

Kondisi lingkungan hidup semakin parah pada era reformasi tersebut karena kewenangannya diserahkan kepada pemerintah daerah berdasarkan UU No 32 tahun 2004. Karena dalam konteks otonomi daerah bidang lingkungan hidup, pengelolaan sumber daya alam di daerah sangat tergantung pada pemimpin daerah (bupati dan wali kota). Tindakan politik mereka seharusnya mencakup aktivitas kebijakan pembangunan yang berorientasi ke perwujudan pembangunan berkelanjutan.

Prinsip yang perlu dikedepankan bagi setiap pemimpin daerah adalah membangun daerah yang selaras dengan prinsip otonomi daerah berkelanjutan. Kepala daerah seharusnya menghitung cermat kapasitas sumber daya alam daerah, memikirkan nasib generasi mendatang, serta kenaikan kualitas kehidupan anak negeri dan tetangga sebumi (Sunoto, 1997). Guna mewujudkan sustainable development sudah seharusnya pemerintah membuat kebijakan dan program yang mendukung kelestarian lingkungan hidup. Salah satu kebijakan yang berpihak kepada kepentingan lingkungan adalah UU No 26 tahun 2007 tentang Penataan Ruang yang didalamnya memuat ketentuan tentang penyediaan Ruang Terbuka Hijau (RTH). 
UU No. 26 Tahun 2007 tentang Penataan Ruang mengamanatkan perencanaan tata ruang wilayah kota harus memuat rencana penyediaan dan pemanfaatan RTH yang luas minimalnya sebesar $30 \%$ dari luas wilayah kota. RTH di perkotaan terdiri dari RTH Publik dan RTH privat dimana proporsi RTH pada wilayah perkotaan adalah sebesar minimal $30 \%$ yang terdiri dari $20 \%$ RTH publik dan $10 \%$ terdiri dari RTH privat. Proporsi $30 \%$ merupakan ukuran minimal untuk menjamin keseimbangan ekosistem kota, baik keseimbangan sistem hidrologi dan keseimbangan mikroklimat, maupun sistem ekologis lain yang dapat meningkatkan ketersediaan udara bersih yang diperlukan masyarakat, serta sekaligus dapat meningkatkan nilai estetika kota. Target luas sebesar $30 \%$ dari luas wilayah kota dapat dicapai secara bertahap melalui pengalokasian lahan perkotaan secara tipikal. Ketentuan tersebut juga dimuat dalam Permen PU No. 5 Tahun 2008 tentang Pedoman Penyediaan dan Pemanfaatan Ruang Terbuka Hijau di Kawasan Perkotaan.

Namun fakta di lapangan menyatakan bahwa keberadaan RTH yang jauh dari proporsi ideal, kekuatan pasar yang dominan merubah fungsi lahan sehingga keberadaan RTH semakin terpinggirkan bahkan diabaikan fungsi dan manfaatnya. Tata ruang yang diharapkan dapat mengakomodasi seakan tidak berdaya menahan mekanisme pasar. Sejumlah areal di perkotaan, dalam beberapa dasawarsa terakhir ini, ruang publik, telah tersingkir akibat pembangunan gedung-gedung yang cenderung berpola "kontainer" (container development) yakni bangunan yang secara sekaligus dapat menampung berbagai aktivitas sosial ekonomi, seperti mall, perkantoran, hotel, dan sebagainya, yang berpeluang menciptakan kesenjangan antar lapisan masyarakat. Hanya orang-orang kelas menengah ke atas saja yang "percaya diri" untuk datang ke tempat-tempat semacam itu.

Karena itu kebijaksanaan pertanahan di perkotaan yang sejalan dengan aspek lingkungan hidup adalah jaminan terhadap kelangsungan ruang terbuka hijau. Ruang terbuka hijau ini mempunyai fungsi "hidro-orologis", nilai estetika dan seyogyanya sekaligus sebagai wahana interaksi sosial bagi penduduk di perkotaan. Taman-taman di kota menjadi wahana bagi kegiatan masyarakat untuk acara keluarga, bersantai, olah raga ringan dan lainnya. Demikian pentingnya ruang terbuka hijau ini, maka hendaknya semua pihak yang terkait harus mempertahankan keberadaannya dari keinginan untuk mengubahnya (Hakim, 2000).

Penelitian ini ingin melihat pelaksanaan kebijakan tentang penyediaan Ruang Terbuka Hijau tersebut di kota Semarang. Dipilihnya Semarang karena kota ini telah memiliki peraturan daerah (Perda) sebagai pelaksanaan dari UU No 26 Tahun 2007 yaitu Perda No 7 tahun 2010. Semarang juga telah meraih penghargaan Adipura sebagai kota yang bersih dan hijau (clean and green city), dimana salah satu kriteria penilaiannya adalah penyediaan Ruang Terbuka Hijau (Istibsaroh, 2013)

Selain itu, pada tahun yang sama (2012) kota Semarang juga terpilih sebagai Kota Hijau (Green City). Bersama sembilan kota lainnya kota Semarang juga terpilih sebagai sebagai proyek percontohan untuk Program Pengembangan Kota Hijau (P2KH). Program Pengembangan Kota Hijau (P2KH) merupakan program yang dikoordinasikan oleh pemerintah provinsi dan difasilitasi oleh Pemerintah Pusat melalui Kementerian Pekerjaan Umum (PU) untuk mewujudkan kota hijau 
di Indonesia. Program ini sendiri memiliki 3 fokus atribut kota hijau, yaitu rencana tata ruang kota hijau (green planning and design), ruang terbuka hijau (green open space) dan pembentukan komunitas hijau (green community) (Rukmana, 2014).

Dengan diraihnya berbagai penghargaan tersebut apakah berarti penyediaan Ruang Terbuka Hijau di Kota Semarang telah terpenuhi sesuai peraturan? Hal itulah yang akan dijawab dalam penelitian ini. Tipe yang digunakan dalam penelitian ini adalah kualitatif deskriptif; yang berupaya mengungkapkan fenomena sosial politik dengan jelas dan cermat (Moleong, 2004). Hal ini dikarenakan penelitian ini berupaya untuk memberikan gambaran mengenai bentuk-bentuk partisipasi masyarakat dan orang/pihak yang berperan menumbuhkan partisipasi masyarakat serta peran dari pemerintah kota.

Sumber data dalam penelitian ini adalah kata-kata dan tindakan para informan sebagai data primer dan tulisan atau dokumen-dokumen yang mendukung pemyataan informan. Adapun teknik-teknik pengumpulan data yang dilakukan dalam penelitian ini, pertama, wawancara terstruktur, yaitu wawancara dengan informan secara individual dengan tetap mengacu pada panduan wawancara yang disusun secara terbuka. Wawancara dilakukan terhadap key person (informan kunci), yaitu orang yang dianggap tahu tentang Pengelolaan Lingkungan Hidup di Kota Semarang yaitu Bappeda, Dinas Tata Ruang, Badan Lingkungan Hidup (BLH), Komis C DPRD dan LSM Bintari. Selain wawancara, kedua, penulis juga menggunakan observasi (pemantauan) dengan mengamati aktivitas, dan pelaksanaan RTH di Kota Semarang, khususnya lokasi-lokasi dibangunnya RTH. Tidak hanya itu, ketiga, penulis juga memakai kajian dokumentasi. Hal ini merupakan upaya untuk mendapatkan data sekunder yang berasal dari buku panduan organisasi atau program, laporan kegiatan, evaluasi program, maupun dari berbagai buku literatur, majalah, jurnal, surat kabar juga internet.

\section{Program Ruang Terbuka Hijau di Kota Semarang}

Menurut UU No 26 tahun 2007, Ruang Terbuka Hijau terdiri dari RTH Publik dan RTH Privat. Berdasarkan Perda No 7 tahun 2010 rencananya RTH Kota Semarang sesuai RTRW seluas kurang lebih 11.211 hektar meliputi: ruang terbuka hijau privat dikembangkan seluas $10 \%$ dari luas wilayah kota dengan luas kurang lebih 3.737 hektar; dan ruang terbuka hijau publik dikembangkan seluas $20 \%$ dari luas kota dengan luas kurang lebih 7.474 hektar.

Komponen penataan RTH menurut pasal 9 Perda No 7 Tahun 2010 meliputi kawasan lindung dan kawasan budidaya. Komponen RTH pada kawasan Lindung, dikembangkan pada kawasan yang telah ditetapkan dengan fungsi utama untuk melindungi kelestarian lingkungan hidup yang mencakup sumberdaya alam dan sumberdaya buatan. Sedangkan komponen RTH pada kawasan Budidaya, dikembangkan pada kawasan yang telah ditetapkan dengan fungsi utama untuk dibudidayakan atas dasar kondisi dan potensi manusia dan sumber daya buatan. 
Adapun bentuk program RTH di Kota Semarang antara lain:

1. Taman Kehati

Program ini bertujuan untuk mendukung pencadangan sumber daya alam hayati guna penyelamatan berbagai jenis tumbuhan lokal yang memiliki tingkat ancaman tinggi. Pengembangan Taman Keanekaragaman Hayati (Taman Kehati) dilaksanakan dengan memperhatikan manfaat dan fungsi ekosistem.

Taman Kehati Kota Semarang merupakan kerja sama antara Pemerintah Kota Semarang, dalam hal ini adalah Badan Lingkungan Hidup dengan Dinas Pariwisata Kota Semarang, berlokasi di Kebun Binatang Mangkang dan Hutan Wisata Tinjomoyo, Badan Lingkungan Hidup Kota Semarang dengan Dinas Pertamanan Kota Semarang berlokasi di depan SMAN 1 Semarang.

\section{Rantai Emas}

Mengingat pemanfaatan pantai dan hutan mangrove yang terus meningkat, terutama untuk kegiatan permukiman dan tambak, maka perlu dipertahankan pelestarian jalur hijau pantai, khususnya mangrove sebagai tempat pembentukan ekosistem hutan mangrove dan tempat perkembangbiakan berbagai jenis biota laut. Jalur pantai tersebut mempunyai fungsi mempertahankan lahan pantai yang telah ditetapkan peruntukkannya, agar fungsi dan kekhasan ekosistem yang ada didalamnya dapat terjaga dengan baik. Untuk mewujudkan tujuan tersebut upaya pemberdayaan masyarakat pantai (pesisir) sangat diperlukan demi kelestarian ekosistem dan fungsi linkungan dari hutan mangrove tersebut.

Hal ini telah menumbuhkan kelompok-kelompok pemerhati lingkungan, di mana kelompokkelompok tersebut saat ini aktif untuk terus membina kelestarian fungsi lingkungan disekitarnya. Kelompok-kelompok tersebut diantaranya adalah Kelompok Pecinta Alam Prentjak dukuh Tapak Kelurahan Tugurejo Kecamatan Tugu, Biota Foundatin dari Kelurahan Mangunharjo kecamatan Tugu, Kelompok Nelayan Camar Tambaklorok Kelurahan Tanjungmas, Kelompok Tani Nelayan Sringin Kelurahan Trimulyo Kecamatan Genuk, Kelompok Pecinta Alam Kesemat, Green Comunity Unes, dan KKM Kota Semarang.

\section{Hutan Kota}

Selain lokasi-lokasi taman dan ruang terbuka hijau tersebut di atas, Kota Semarang juga berupaya terus untuk melakukan kegiatan penghijauan di seluruh wilayah kecamatan. Hal ini dilakukan dengan terus mendorong masing-masing wilayah kecamatan untuk melakukan penghijauan di lahan-lahan kosong di masing-masing wilayah kecamatan. Sedangkan pemanfaatan lahan untuk hutan kota, saat ini Pemerintah Kota Semarang telah memiliki beberapa lokasi hutan kota, yaitu Hutan Kota Tinjomoyo, Hutan Krobokan, Hutan Kota Gunung Talang. Pada tahun 2012 telah ditetapkannya secara kekuatan hukum sejumlah lokasi hutan kota tersebut dalam bentuk Surat Keputusan Walikota Semarang. 


\section{4. $\mathrm{P} 2 \mathrm{KH}$}

P2KH adalah Program Penembangan Kota Hijau di kota Semarang, dimulai Tahun 2011 sampai dengan sekarang, merupakan salahsatu program (pilot project) dari Kementerian Pekerjaan Umum di Kota Semarang sebagai implementasi UU nomor 32 tahun 2009 pada Kementerian PU.

\section{Grand Design Mangrove dan DED Eko Edu Wisata Mangrove Kota Semarang}

Berdasarkan pola ruang wilayah Kota Semarang, kawasan pantai berhutan bakau/mangrove adalah kawasan pesisir laut yang merupakan habitat alami hutan bakau yang berfungsi memberi perlindungan kepada perikehidupan pantai dan lautan. Kawasan tersebut ditetapkan di kecamatan Tugu dan kecamatan Genuk meliputi: Kelurahan Mangunharjo, Mangkang Kulon, Mangkang Wetan, Randugarut, Karanganyar, Tugurejo, Terboyo Kulon dan Trimulyo.

\section{One Billion Trees / Penanaman Sejuta pohon}

Pemerintah Kota Semarang beserta seluruh warga kota mencanangkan komitmen yang tinggi serta program yang konsisten dalam melaksanakan upaya rehabilitasi hutan dan lahan dan konservasi lingkungan termasuk biodiversitasnya. Kegiatan rehabilitasi dan konservasi ini menunjukkan komitmen Pemerintah Kota Semarang bahwa sumberdaya hutan merupakan salah satu penggerak perekonomian bangsa, penyediaan lapangan pekerjaan bagi rakyat, pengentasan kemiskinan dan sekaligus mampu menghasilkan produk yang ramah lingkungan.

\section{Pelaksanaan dan Evaluasi}

Dari hasil penelitian diketahui bahwa pelaksanaan Perda No 7 Tahun 2010 tentang Penataan RTH di Kota Semarang telah terpenuhi. Capaian sampai tahun 2013 telah sesuai peraturan yaitu sebesar $40 \%$. Angka tersebut melampaui target minimal yang harus dipenuhi yaitu minimal $30 \%$; yang terdiri dari RTH Publik dan RTH Privat. Walaupun pelaksanaan Perda ini belum bisa dilihat secara tuntas karena sesuai RTRW yang masa berlakuknya 20 tahun (2011-2030). Sedangkan penelitiannya hanya melihat selama kurun waktu sekitar 3 tahun (2011-2013) saja.

Masalahnya pencapaian tersebut bersifat keseluruhan untuk seluruh Kota Semarang. Sumbangan terbesar dari dari kawasan pinggiran seperti Gunung Pati dan Mangkang yang memang belum banyak pemukimannya. Akan tetapi khusus kawasan dalam perkotaan belum mencapai $30 \%$. Sementara kalau dihitung perkecamatan targetnya juga tidak terpenuhi; seperti Semarang Tengah yang capaiannya di bawah 15\%. Kepala Dinas Pertamanan Kota Semarang sendiri mengatakan RTH kawasan dalam perkotaan baru mencapai $7 \%$. Hal tersebut diperkuat sumber informasi dari LSM Bintari mengatakan RTH kawasan dalam perkotaan tidak sampai $10 \%$.

Dari waktu ke waktu semakin banyak bangunan-bangunan perkantoran, hotel, pertokoan hingga mall berdiri di tengah Kota Semarang. Bahkan Semarang dijuluki sebagai kota seribu ruko. Hal tersebut tentu berkontribusi mengurangi ketersediaan RTH. Walaupun syarat pendirian 
bangunan-bangunan tersebut harus menyediakan lahan untuk RTH namun seringkali aturan tersebut dilanggar, seperti penyediaan sumur resapan/drainase.

Demikian juga kebutuhan akan ruang publik di kota Semarang sebetulnya sangatlah tinggi. Namun ketersediaannya sangat sedikit; seperti Simpang Lima dan Taman KB. Akhirnya seringkali terjadi salah kaprah. Mall dijadikan sebagai ruang publik, padahal mall bukanlah ruang publik tapi ruang privat. Di dalam mall tidak ada ruang publik. Pengunjungnya pun terbatas kalangan menengah ke atas.

Sebenarnya kalau dilihat secara regulasi sudah sangat memadai karena Kota Semarang memiliki Perda tentang Penataan RTH. Namun dalam pelaksanaanya ternyata masih banyak yang harus dibenahi. Demikian juga dalam pengawasan dan penegakan hukum yang masih sangat lemah. Dalam regulasi diatur mengenai sanksi bagi pelanggaran; mulai dari pelanggaran administratif hingga tindak pidana itu memungkinkan. Tetapi instrumen penegak hukumnya masih lemah dan pemerintah sendiri masih melakukan pembiaran dan tidak adanya pengawasan.

Disamping itu, pemerintahan juga harus memperhatikan pertambahan jumlah penduduk yang mengakibatkan terjadinya densifikasi penduduk dan permukiman yang cepat dan tidak terkendali di bagian kota. Hal tersebut menyebabkan kebutuhan ruang meningkat untuk mengakomodasi kepentingannya. Semakin meningkatnya permintaan akan ruang khususnya untuk permukiman dan lahan terbangun berdampak kepada semakin merosotnya kualitas lingkungan. Rencana Tata Ruang yang telah dibuat tidak mampu mencegah alih fungsi lahan di perkotaan sehingga keberadaan Ruang Terbuka Hijau (RTH) semakin terancam dan kota semakin tidak nyaman untuk beraktivitas.

Kondisi Kota Semarang yang beberapa tahun rajin berbenah menata kota turut memberi andil diraihnya penghargaan Adipura selama dua tahun berturut-turut (tahun 2011 dan 2012). Jalan-jalan diperbaiki, seperti Jalan Pemuda, Jalan Pahlawan, juga Kawasan Tugumuda. Ditambah dengan direlokasikannya PKL di trotoar Simpang Lima. Namun apakah sebenarnya kota Semarang layak mendapatkannya piala Adipura?

Adipura mensyaratkan clean dan green city. Adapun RTH hanyalah merupakan salah satu komponen penilaian dalam Adipura. Beberapa komponen lainnya adalah kualitas air dan kualitas udara serta kebersihan. Menurut UU no 26 tahun 2007, suatu kota berhak mendapat Adipura jika RTH-nya mencapai sebanyak 20\%. Adapun capaian Kota Semarang RTH nya sebesar $40 \%$ karena itu Kota Semarang masuk dalam kategori pantas mendapat Adipura.

Kenyataannya target tersebut terpenuhi jika dihitung secara keseluruhan. Namun jika dipandang per-kecamatan Kota Semarang tidak memenuhi target, kecuali di beberapa kecamatan pinggiran seperti Gunungpati dan Mangkang. Tim penilai Adipura seharusnya melihat keseluruhan kota, tidak hanya sample karena RTH Kota Semarang sebenarnya kurang dari $30 \%$.

Penilaian yang dilakukan terhadap seluruh kabupaten/kota di Indonesia dalam waktu satu tahun menjadikan hasilnya bisa saja kurang valid. Karena itu salah satu usulannya kriteria penilaian 
Adipura seharusnya ditambah. Misalnya bukan hanya pada ketersediaan RTH, kebersihan, dan kualitas air serta udara. Namun pemberian izin yang melanggar aturan juga harus dinilai. Jika terjadi pelanggaran harus ada punishment. Apalagi Adipura diberikan sebagai bentuk reward, sudah seharusnya diimbangi dengan adanya punishment. Penyelenggaraan Adipura pun dinilai kurang memberikan banyak manfaat dan hanya memboroskan anggaran negara maupun pemerintah daerah. Bahkan beberapa daerah berupaya melakukan suap untuk mendapatkan penghargaan tersebut, sebagaimana yang terjadi di Bekasi.

Demikian juga halnya dengan predikat Kota Semarang sebagai Kota Hijau (Green City) yang diperoleh pada tahun 2012. Dengan diraihnya penghargaan tersebut berarti target RTH 30\% telah terpenuhi sesuai dengan Perda No 7 tahun 2010. Namun khusus wilayah dalam perkotaan masih belum tercapai. Hal ini menjadi titik tekan yang harus ditingkatkan oleh pemerintah Kota Semarang karena Green City fokusnya pada daerah perkotaan, yakni pada tiga atribut hijau: Tata ruang kota hijau, Ruang terbuka hijau, dan Pembentukan komunitas hijau.

\section{Penutup}

Dari hasil studi ruang terbuka hijau pada kebijakan pengelolaan lingkungan hidup di Kota Semarang ,dapat disimpulkan bahwa penyediaan RTH di Kota Semarang telah sesuai dengan Perda No 7 Tahun 2010. Target minimal 30\% telah tercapai sampai tahun 2013 ini. Sayangnya capaian tersebut bersifat keseluruhan. Akan tetapi untuk kawasan dalam perkotaan sendiri belum terpenuhi, juga kalau dihitung per kecamatan. Capaian terbanyak justru terdapat pada kawasan pinggiran seperti Gunungpati. Padahal menurut UU seharusnya RTH lebih banyak di kawasan dalam perkotaan.

Dengan diraihnya beberapa penghargaan di bidang lingkungan hidup seperti Adipura dan predikat sebagai Kota Hijau sangat berhubungan dengan ketersediaan RTH. Pencapaian RTH yang telah memenuhi syarat minimal $30 \%$ memberi andil bagi diberikannya penghargaan tersebut. Walaupun RTH hanya merupakan salah satu komponen penilaian. Catatannya capaian $30 \%$ jika dihitung secara keseluruhan. Namun untuk kawasan perkotaan justru belum tercapai. Artinya secara kuantitatif Kota Semarang layak menerimanya, tetapi masih kurang layak secara kualitatif. Karena penilaian seringkali hanya bersifat simbolis dan sesaat. Hijau dan asrinya kota Semarang ternyata lebih banyak di kawasan pinggiran. Sementara kawasan dalam perkotaan masih sangat kurang. Yang bertambah justru bangunan-bangunan yang menggusur keberadaan lahan RTH seperti hotel, pertokoaan, perkantoran dan mall yang jumlahnya dari waktu ke waktu semakin banyak.

Adapun kendala dalam pelaksanaan penataan RTH adalah masalah pendanaan, pengawasan \& penegakan hukum, serta komitmen pemerintah kota Semarang. Political will pemerintah Kota Semarang dalam membuat kebijakan yang berpihak pada kepentingan lingkungan ini belum didukung oleh pendanaan yang cukup memadai maupun komitmen dalam pengawasan dan 
penegakan hukum. Kurangnya partisipasi masyarakat dan pihak swasta juga menjadi kendala yang harus ditingkatkan oleh pemerintah Kota Semarang.

Dengan kesimpulan semacam itu, maka Pemerintah Kota Semarang harus lebih serius dan berkomitmen untuk mewujudkan penataan RTH dengan lebih baik lagi. Artinya, angka $30 \%$ harus tercapai, utamanya pada kawasan dalam perkotaan. Regulasi yang ada harus diturunkan dalam bentuk rencana aksi dan strategi yang lebih jelas. Pemerintah harus berani menambah anggaran untuk pelaksanaan kebijakan penataan RTH ini. Karena bidang lingkungan selalu membutuhkan banyak dana sementara hasilnya baru bisa dinikmati dalam jangka panjang. Pemerintah harus meningkatkan partisipasi aktif masyarakat dan pihak swasta demi kesuksesan kebijakan ini. Dana pihak swasta seperti CSR bisa dimanfaatkan. Dengan pengelolaan yang baik dana yang diperoleh akan sangat membantu pemerintah dalam pelaksanaan RTH, seperti penanaman pohon, pembuatan taman, dan sebagainya.

\section{Ucapan Terima Kasih}

Terima kasih pada seluruh narasumber dan rekan kerja penulis di Departemen Ilmu Politik dan Pemerintahan, Universitas Diponegoro.

\section{Pendanaan}

Penulis tidak menerima bantuan pembiayaan untuk penelitian, kepenulisan (authorship), dan publikasi dari pihak manapun.

\section{Daftar Pustaka}

Hakim, R. (2000). Analisis Kebijakan Pengelolaan Ruang Terbuka Hijau Kota DKI Jakarta. Institut Teknologi Bandung.

Istibsaroh, N. (2013). Semarang Kembali Raih Piala Adipura. Diakses pada 3 November 2016, dari https://jateng.antaranews.com/berita/80085/semarang-kembali-raih-piala-adipura

Maulana, A. (2012). Kebijakan Lingkungan Hidup di Indonesia Belum Sepenuhnya Optimal. Diakses pada 5 Mei 2013, dari http://www.unpad.ac.id/2012/09/kebijakan-lingkungan-hidup-diindoensia-belum-sepenuhnya-optimal/

Moleong, L. J. (2004). Metode Penelitian Kualitatif. Bandung: Remaja Rosda Karya.

Rukmana, D. (2014). Pelaksanaan P2KH 2012-2014 (Instrumen Implementasi RTR). Diakses pada 4 November 2015, dari http://www.tataruangpertanahan.com/file_peratur an/51020140917103208_238965549-evaluasi-program-kota-hijau-p2kh.pdf

Sunoto. (1997). Analisis Kebijakan dalam Pembangunan Berkelanjutan. Bahan Pelatihan Analisis Kebijakan Bagi Pengelola Lingkungan, antor Menteri Negara Lingkungan Hidup. 
Supratiwi

\section{Tentang Penulis}

Supratiwi adalah Dosen Departemen Politik dan Pemerintahan, Fakultas Ilmu Sosial dan IImu Politik, Universitas Diponegoro. Area riset yang digeluti adalah otonomi daerah dan politik lingkungan. 